\title{
Study of Ami Maka Ana ( Traditional Fermented Buffalo Milk ) as Nutritional Food at Los Palos East Timor
}

\author{
I Made Sugitha ${ }^{1 .}$, Ni Nyoman Puspawati ${ }^{1}$ and Amadeu de Lopez ${ }^{2}$ \\ ${ }^{1)}$ Food Science and Technology, Faculty of Agricultural Technology \\ Udayana University at Jimbaran, Bali Indonesia \\ E-mail: madesgt@yahoo.com \\ ${ }^{2)}$ Postgraduate Food Science and Technology, Faculty of Agricultural Technology \\ Udayana University at Jimbaran, Bali Indonesia
}

\begin{abstract}
The study was conducted to determine the public attitude toward the existence of traditional food ami maka-ana (AMA)prepared by addition of maka wele (alip-bark) in to buffalo milk at Locales. The method used were explorative and laboratory research, for determining the location was based on the method of purposive sampling, in which 4 villages in the sub district of Locales was chosen as the location of the study. The samples of AMA were collected from each village which were tested organoleptically and chemical composition at Food Nutrition Laboratory of FTP-Unud Denpasar, Bali, Indonesia. The results showed that Panelists were like the taste and overall acceptance by its characteristics such as moisture $(\mathbf{5 0 . 1 5 \%})$, ash ( $2.00 \%)$,

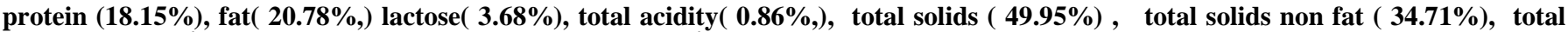
count $\left(5.65 \times 10^{4} \mathrm{CFU} / \mathrm{g}\right)$ and lactic acid bacteria $\left(2.15 \times 10^{4} \mathrm{CFU} / \mathrm{g}\right)$.
\end{abstract}

Keywords — buffalo milk, and ami maka-ana., maka wele

\section{INTRODUCTION}

Timor-Leste is a tropical country with an area of 14,874 km2 which lies between Indonesia and Australia. As a tropical country with a population of 1.133 million people, Timor-Leste has enormous natural potential to be developed as a real contribution to national development. National development in order to improve people's lives focusing on rural development. It is based on a demographic considerations that indicate by the population of TimorLeste approximately $84 \%$ live in rural and subsistence farmers [3].

Diversification of animal-based food buffalo milk is expected to cover the shortage of milk production in the country and reduce imported milk from other countries that drain the country's foreign exchange. When the buffalo dairy products can be developed it is expected that the buffalo dairy farm business can be improved. However, the government has not attention for buffaloes developing farm , whereas buffaloes are tropical animals that can adapt to the tropical climate of Timor-Leste, that plays an important role as a working farm, a source of meat, milk and transportation resources in rural areas. At Los Palos area there is processed products from buffalo milk as a curd-like appearance called Ami Maka Ana (AMA)( Fig. 3). The AMA manufacturing process is very simple; in which is the fresh buffalo milk poured into the scene of panic and dipped an Alip-bark (they call maka wele, ) (Fig.2.) then heated for 45-60 minutes until the clot is produced. AMA is one of the traditional food, very tasty and healthy that preferred and commonly consumed as a side dishes of the people at Los Palos. Based on the above facts, AMA is a unique traditional food and very interesting to study.

Administratively, the sub district of Los Palos consist of 10 villages, with a total area of $624 \mathrm{~km} 2$ with total population was 29711 ( 15055 man and 14656 woman) and 4,164 head of buffaloes. Generally, buffaloes still maintained with a traditional method, but potentially able as : a source of labor, meat, milk, producing manure, and craft materials, however the buffalo also used as an indicators of high social rank among the public, especially at weddings, events and death rituals.

Alip- bark has been known as a coagulant agent for manufacturing of traditional buffalo milk (ami maka ana) by most people at Fataluku Lautem since ancestors. In Indonesia, Alip known by the trade name Rampelas, also 
known as as hampelas (Malay), hampelas (Sunda), rampelas (Java), somoma (Halmahera) and sosoma (Ternate). In the description mentioned that habitus: tree, $10-20 \mathrm{~m}$ tall; stems: erect, rounded, branching simpodial, rough surface, brownish green; leaf: single, alternate, oval, serrated edge, pointed tip, base tapered, 15-18 cm long, 4-6 cm wide, rough surface, pinnate, green; flower: single, and seeds: round, white; and taproot (Anon., 2010b). Further stated also that the leaves, roots and stems F. ampelas contains of chemicals such as saponins, flavonoids, polyphenols and tannin. These chemicals are similar to the crown god tree that used as : boost the immune system, anti-inflammatory, and as an antihistamine .

\section{Research Methodology}

Implementation of the research took place in two stages such as exploratory and laboratory research. Principal parameters observed in this study are: characteristics, knowledge and perceptions of the respondents were associated with respondents' attitudes through interviews. While other parameters measured were: organoleptic sensory ebaluation test, water, protein, fat, lactose content, solids non fat and total solids, total acid, total microorganism and total Lactic Acid Bacteria content .

\section{RESULTS AND DISCUSSION}

People who like AMA is $(66.67 \%)$ included in the working age group, while the remaining $(33.33 \%)$ were in the elderly group. Old group is the most widely know and take pride in the presence of AMA. Of the elderly should be able to transfer the knowledge to younger age group AMA so as to know the AMA and maintain its existence as a traditional food.

Dry land of the villages can be used extensively for farming system ( plantation also be used for raising livestock). The dry land ownership and the availability of a vast desert expanse, considered the potential for the maintenance and development of buffalo breeding for meat, milk used as raw material for the manufacture of AMA. This means that large amounts of land owned by a person closely related to the attitude of the person ability to develop the farm, which was originally a small farm into a big business. More or less animals own by the people will affect the motivation of farmers to be more active and more positive attitude toward traditional food AMA or in to the field of animal husbandry.

The attitudes significantly different influenced by the knowledge and perceptions of the respondents ( maintaining traditionally the habit of insisting heritage). Different attitudes of each village can be accepted in a reality for using raw buffalo milk and Alip bark as the coagulant, but since the era ancestor until now there has no been process for making AMA standard in each of the vilage. In addition, the presence of AMA in the sub district of Los Palos has not been touched by Science and Technology).

\section{A. Sensory evaluation}

Sensory evaluation conducted by hedonic and scoring test (Soekarto, 1985). Hedonic test is used to determine the level of AMA acceptance include the taste, flavor, and overall acceptance, while for color and texture evaluation was done by scoring test. The panelist used in this evaluation as many as 30 peoples.

TABEL I

The Average Of Organoleptic SEnSORy Evaluation Of AMA

\begin{tabular}{|l|l|l|l|l|l|}
\hline \multirow{2}{*}{ Parameter } & \multicolumn{4}{|c|}{ Village } & \multirow{2}{*}{$\begin{array}{c}\text { Mean } \\
\text { Scor }\end{array}$} \\
\cline { 2 - 5 } & Fuiloro & Bauró & Raça & Home & \\
\hline & & & & & \\
Color & 6,4 & 6,4 & 6,4 & 6,3 & 6,4 \\
Tekstur & 4,1 & 4,1 & 4,4 & 4,4 & 4,3 \\
Flavor & 6,3 & 6,3 & 6,2 & 6,2 & 6,3 \\
Taste & 6,7 & 6,7 & 6,5 & 6,3 & 6,6 \\
Acceptance & 6,7 & 6,7 & 6,6 & 6,4 & 6,6 \\
\hline
\end{tabular}

The average data of sensory evaluation was taken from the best AMA prepared of each village (Table 1). From the results of the mean sensory evaluation score such as : color : 6.4 (yellowish white), texture 4.3 (regular / neutral), aroma 6.3 (love), taste 6.6 (really like), and overall acceptance 6, 6 (really like). AMA texture with an average score of $4.3 \%$ is said regular / neutral. AMA texture with neutral category is due to the water content. The results of the taste test and showed that the overall acceptance panelists like the food very much, then it is an indication that the sub-district of Los Palos community remains positive about the existence of traditional food (AMA).

\section{B. AMA Nutrition Analysis}

The water content, protein content, fat content, ash content, lactose content, total acid, and total solids content of AMA were used as parameters that analyzed in the laboratory include total colony and lactic acid bacteriacount . Data analysis of the nutrient content of food traditional AMA was presented in Table 2.

TABEL II.

ANALISIS DATA OF NUTRIENT CONTENT OF 100 G AMA.

\begin{tabular}{|l|c|c|c|c|c|c|c|c|c|c|}
\hline Village & Water $(\%)$ & $\begin{array}{c}\text { Ash } \\
(\%)\end{array}$ & $\begin{array}{c}\text { Protein } \\
(\%)\end{array}$ & Fat $(\%)$ & $\begin{array}{c}\text { Laktosa } \\
(\%)\end{array}$ & $\begin{array}{c}\text { Total Acid } \\
(\%)\end{array}$ & $\begin{array}{c}\text { Total } \\
\text { solid }(\%)\end{array}$ & $\begin{array}{c}\text { PBL } \\
(\%)\end{array}$ & $\begin{array}{c}\text { Total colony } \\
(\mathrm{cfu} / \mathrm{g})\end{array}$ & $\begin{array}{c}\text { Total LAB } \\
(\mathrm{cfu} / \mathrm{g})\end{array}$ \\
\hline Fuiloro & 49.63 & 2.23 & 21.05 & 17.01 & 3.77 & 0.76 & 50.73 & 30.90 & $6.95 \times 10^{4}$ & $1.21 \times 10^{4}$ \\
\hline Raça & 49.95 & 1.78 & 17.43 & 22.61 & 3.40 & 0.98 & 50.05 & 28.00 & $3.55 \times 10^{4}$ & $1.16 \times 10^{4}$ \\
\hline Home & 50.06 & 1.80 & 16.57 & 25.00 & 3.74 & 0.72 & 49.95 & 34.47 & $5.1 \times 10^{4}$ & $0.88 \times 10^{4}$ \\
\hline Bauró & 50.95 & 2.20 & 17.55 & 18.48 & 3.81 & 0.96 & 49.05 & 45.46 & $7 \times 10^{4}$ & $5.36 \times 10^{4}$ \\
\hline Average & 50.15 & 2.00 & 18.15 & 20.78 & 3.68 & 0.86 & 49.95 & 34.71 & $5.65 \times 10^{4}$ & $2.15 \times 10^{4}$ \\
\hline
\end{tabular}


As a traditional food made from buffalo milk is coagulated by addition of Maka Wele Table 2 show the nutritional value of AMA produced in the sub district of Los Palos. However, in manufacturing process sanitation should be considered to produce AMA in a good quality and safe for consumption. The water content of $50.15 \%$ (Table 2) indicated that AMA almost the same as semi hard cheese (44 to $55 \%$ ) [8].

The protein content of AMA $18.15 \%$ relatively normal levels of the food, further explained that this protein is obtained from the modified casein to the curd. The one adventage of the fermented milk products (AMA, Dadih, yogurt) can used as protein soucer doe to the essential amino acid content [10]

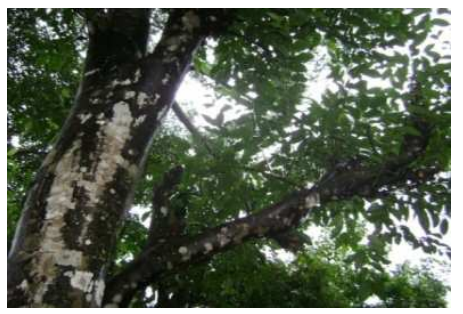

Fig.1. Alip-bark( Ficus ampelas Burn.f)

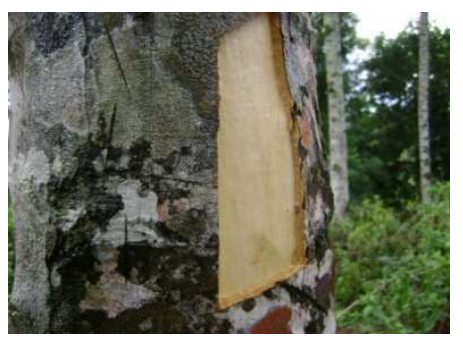

Fig,2. Alip plan ( Ficus ampelas Burn.f )

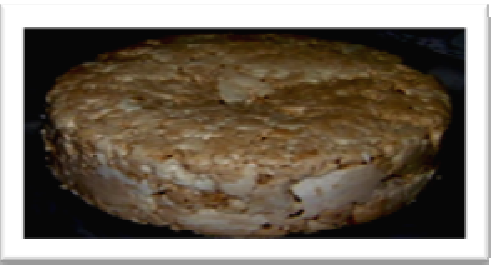

Fig.3. Ami Maka Ana (AMA)

The levels fat in the AMA was at $20.78 \%$. it was higher than the average composition of milk (cows milk) 3.6\% [5] High levels of fat can give a unique flavor and nice texture of the AMA. The composition of the AMA fat may be influenced by some factors including a genetic trait buffaloes, the lactation period, the state of the environment, food and health and nutritional status of the animal itself. The ash content of the product (2\%). Further explained that a number of factors affecting the diversity in the composition of salts, such as animal feed, season, heredity and individuality such as lactation and milk sac infection. AMA containing $3.68 \%$ lactose, doe to the bufalloes milk carbohydrates were in the form of lactose, which serves as the sweet taste. Another fact the lactose content of the AMA should be known as having a great influence on human life( lactose intolerance people). Total acid AMA is
$0.85 \%$. expressed by titration of lactic acid produced during fermentation or clotting effect by addition of alip bark. Its Further said that if the titration with alkali and phenolptalin as an indicator, actually the total acids content of milk it was about 0.10 to $0.20 \%$ [10]. Also confirmed that the acidic taste of the milk, mostly do to lactic acid of the milk, however other components such as citric acid, amino acids, and carbon dioxide dissolved in the milk take place to influence the acidity. Total solids content of the AMA was $49.95 \%$, while the solids not fat is $34.91 \%$ (Table 2).

TABLE III

The Average Composition OF MiLK ANd Buffalo’MilK

\begin{tabular}{|l|l|l|}
\hline Componen & Milk & Buffalow'Milk \\
\hline Fat (\%) & 3.90 & 7.40 \\
\hline Protein (\%) & 3.40 & 4.74 \\
\hline Lactose (\%) & 4.80 & 4.64 \\
\hline Ash (\%) & 0.72 & 0.78 \\
\hline Water (\%) & 87.10 & 82.44 \\
\hline $\begin{array}{l}\text { Total Solid } \\
(\%)\end{array}$ & 12.90 & 17.56 \\
\hline
\end{tabular}

As we see at Table 3, the solid content of raw buffaloes milk $(17.56 \%)$ were much different than total solid of the AMA, The reason doe to water content that evavorated during heating process while its manufactured. The highest total mikro organism count of AMA is $7.1 \times 104 \mathrm{CFU} / \mathrm{g}$, was produced at Raca village ( Table 2) The presence of micro organism in AMA may be an indicator of poor sanitation process and contamination possibility in the process of packing and shipping the samples from Timor Leste to Food Chemistry analysis laboratory at Technology agricultural Faculty Udayana University Denpasar Bali Idonesia. The properties of the milk may change effectively by the activity of the microorganisms in AMA . Lactic acid bacteria (LAB) analysis data in Table 2 shows that the AMA samples taken from four villages in an average of $2.15 \mathrm{x}$ $104 \mathrm{CFU} / \mathrm{g}$. LAB contained in the AMA may be derived from the bark of Alip, so it can also supported for clotting the milk (curd). Curding effect of buffaloes milk may doe to casein precipitated $(80 \%$ milk protein $)$ on the $\mathrm{pH}$ of isoelectrict point ( $\mathrm{pH} 4.7$ ), this condition doe to the onset of lactic acid can cause a drop in the $\mathrm{pH}$ of the milk( Sugitha and Rai, 2012). By knowing AMA contain in amount of lactic acid bacteria (LAB), which is indispensable to the consumers health, so it is expected to open up opportunities for the existence and development of traditional food (AMA), to the high nutritional value and beneficial food to human health in the future.

\section{CONCLUSIONS}

Based on the results, the conclusions can be drawn that .AMA is one of traditional food at Timor Leste should be developed by high technology process for food sustainable, because Food AMA is preferred by panelists in terms of taste and overall acceptance, good quality with objective characteristics of water ( $50.15 \%)$, ash $(2.00 \%)$, , protein $(18.15 \%)$, fat $(20.78 \%)$, lactose $(3.68 \%)$, acidity ( $0,86 \%)$, total solids $(49.95 \%)$, solids not fat $(34.71 \%)$, 
total microorganism count $(5.65 \times 104 \mathrm{CFU} / \mathrm{g})$ and lactic acid bacteria (2.15 x104 CFU/g.). and positive attitudes of Los Palos community for AMA existence

The government and non-governmental agencies Should give attention and support the procurement of high genetic quality of local cattle and buffalo in order to increase the milk production ability of cattle and buffalo, so the existence of AMA will meet the animal protein requirement of Timor Leste community.

Should be conducted a research on alip bark for identification those component that play a role in buffalo milk clotting process and its effect for human health

\section{REFERENCES}

[1] Anonimus. 2010a. Rampelas (Ficus ampelas Burm. f.). http://www.plantamor.com/index.php? plant=577

[2] Anonimus. 2010b. Ficus ampelas Burm. f. http://bebasvelsm12artikelttg_tanaman_obatdepkesbuku33-027.pdf

[3] Barros, A. 2008. Country Report. Ministry of Agriculture and Fisheries Democratic Republic of East Timor. Dili.

[4] Buckle, K.A., R.A. Edwads, G.H. Fleet dan M. Wooton. 1987. Ilmu Pangan. Penterjemah Hari Purnomo dan Adiono. UI Press. Jakarta.

[5] Hadiwiyoto, S. 1994. Teori dan Prosedur Pengujian Mutu Susu dan Hasil Olahannya. Liberty. Yogyakarta.
[6] Mosher, A.T. 1984. Menggerakkan dan Membangun Pertanian Disadur oleh Krisnandi, S. dan Samad, B. CV. Yasaguna. Jakarta.

[7] Murti, T.W. 2007. Beternak Kerbau. PT Citra Aji Parama. Yoyakarta.

[8] Murti, T.W. dan T. Hidayat. 2009. Pengaruh Pemakaian Kultur Tiga Macam Bakteri Asam Laktat dan Pemeraman Terhadap Komposisi Kimia dan Flavor Keju. Fakultas Peternakan Universitas Gadjah Mada. Yogyakarta.

[9] Rukmana, H.R. 2003. Beternak Kerbau, Potensi dan Analisis Usaha. CV. Aneka Ilmu, Anggota IKAPI. Semarang.

[10] Sugitha I Made and I Wayan Rai Widarta., 2012 Teknologi Susu,Daging dan Telur; Buku Arti jalan Pulau Kawe N0. 62 Denpasar.

[11] Soekarto. 1985. Penilaian Organoleptik untuk Industri Pangan dan Hasil Pertanian. Penerbit PT. Bhatara Karya Aksara. Jakarta.

[12] Sosroamidjojo, M.S. 1991. Ternak Potong dan Kerja. C.V. Yasaguna, Jakarta.

[13] Sudarmadji, S., B. Haryono dan Suhardi. 1997. Prosedur Analisa untuk Bahan Makanan dan Pertanian. Edisi Keempat. Liberty. Yogyakarta.

[14] Sugitha, I.M., Husni M. dan Yuherman 1999. Rekayasa Dadih Dengan Starter Streptococcus lactis dan Lactobacillus acidophilus Untuk Mencegah Kanker dan Mengurangi Kolesterol Darah H. B.(Hibah Bersaing) VI, 1997-1999.Depdiknas Dikti.

[15] Wahyudi, A. dan S. Samsundari. 2008. Bugar dengan Susu Fermentasi. UMM Press. Malang 